\title{
EFFECT OF DIETARY GLUTATHIONE, ALUMINOSILICATE AND TAFLA ON LAYING HENS DURING AFLATOXICOSIS
}

\author{
E.M.A. Qota, E.H El-Ganzory and R.A. Hassan
}

Poultry Nutrition Department, Animal Production, Research Institute, ARC, Giza, Egypt

\section{SUMMARY}

An experiment was conducted to evaluate effect of dietary tripeptide glutamate (reduced glutathione (GSH)) as antioxidant, tafla (TF), and hydrated sodium calcium aluminosilicate (HSCAS) as sorbent materials to reduce aflatoxicosis in chickens. A total number of 371 (350 laying hens +21 cocks) thirty-wk old El-Salam chickens were randomly divided into 7 groups; each group included 5 replicates of 10 hens each and housed in metallic batteries. The remaining 21 cocks were also divided into 7 groups of 3 cocks each and housed separately for semen collection. Birds were fed practical corn-soybean meal basal diet with or without 1 ppm aflatoxin $B_{1}\left(A F B_{1}\right)$ alone or plus either $5 \mathrm{ppm}$ GSH, $0.6 \% \mathrm{TF}, 0.5 \% \mathrm{HSCAS}, 0.6 \% \mathrm{TF}+5 \mathrm{ppm}$ GSH or $0.5 \%$ HSCAS+ 5ppm GSH to form 7 diets fed from 30 to 38 wks old. Results show that contamination of basal diet with $1 \mathrm{ppm} A F B_{1}$ for 8 wks decreased $(P<.01)$ feed intake (25.1\%), egg production (42.8\%), egg weight (22.3\%), shell thickness $(32.6 \%)$, fertility (21.9\%), hatchability of fertile eggs (20\%), economic efficiency (EE,38.5\%), liver vitamin A (29.1\%), blood hemoglobin (35.6\%), serum albumin (68\%) and total lipids (51\%), increased relative liver weight (138.8\%), liver lipids (141.9\%), blood total leucocytes (WBC's) (28\%) and lymphocytes (27.2\%) counts, serum enzymatic activities of AST (64\%) and ALT (69\%), and deposited AFB1 residues in livers (68 $\mathrm{ng} / \mathrm{g}$ ), egg yolk (52 $\mathrm{ng} / \mathrm{g}$ ) and muscles (36 $\mathrm{ng} / \mathrm{g}$ ) compared to the controls. Adding TF or HSCAS separately into AF diet recorded similar protection effects averaged $45-56 \%$ against aflatoxicosis for the studied traits. Including GSH alone into the AF diet resulted in a little protective effects against AF diet for the all studied traits, except AST and ALT activities that showed a significant protective effect (20-28\%). However, GSH together with TF or HSCAS significantly negated the adverse effects of AF diet for all studied traits. Supplementing sorbent materials plus GSH with AF-diet improved EE $80.97 \%$ for TF $+G S H$ and $74.87 \%$ for $H S C A S+G S H$ compared to AF-diet. There were mortalities only among two groups fed basal diet with $A F B_{1}$ alone (10\%) and $A F B_{1}+G S H(6 \%)$. The present study revealed that TF presented similar protective effect for studied traits and EE as HSCAS. Adding GSH as antioxidant together with TF or HSCAS, to AFB contaminated diet significantly negated aflatoxicosis in the laying hens.

Keywords: Glutathione, aluminosilicate aflatoxicosis, laying hens, tafla, performance, residues

\section{INTRODUCTION}

Aflatoxin has elicited greatest public health concern of all mycotoxins because of its widespread occurrence in several grains as corn which comprises $50-60 \%$ of poultry diets (Philips et al.,1988), in addition to the role of aflatoxins in the etiology

Issued by The Egyptian Society of Animal Production 
of hepatocellular carcinoma that has been proved (Wiled et al.,1990). The $\mathrm{LD}_{50}$ values for $\mathrm{AF}$ ( $\mathrm{mg} / \mathrm{kg}$ body weight) were 6.5-16.5 in several chicken strains (Smith and Hamilton, 1970; El-Samra. 1991). Depression by about 6-30\% of chick growth (Edrington et al.,1997; Genedy et al.,1999; Qota, 2003), impairment of feed efficiency (Kubena et al., 1995; Qota, 1999; Qota et al., 2005) and higher mortality rate (Abdelhamid et al.,1995a; Qota, 2003; Ali et al., 2006) by 0.5-4ppm AF contaminated diet caused very high economic loses. Inhibition of metabolism and immunity system by $0.75-2 \mathrm{ppm}$ AF contaminated diet caused increasing liver fat (60\% of dry weight) and liver size (2-3 times) and liver damage (Smith et al., 1993; Abd El-Hamid et al., 1992). The same authors reported also that $\mathrm{AFB}_{1}$ inhibits DNA synthesis in the liver and possibly prevents proteins synthesis. The HSCAS at $0.5 \%$ in the diets has been shown to reduce aflatoxicosis in chickens (Scheideler, 1993; Qota et al.,2005; Ali et al., 2006). The HSCAS binds AFB1 in vitro (Philips et al., 1988; Scheideler, 1993). Thus, the efficacy of sorbent materials as HSCAS or Tafla probably lies in their ability to bind $\mathrm{AF}$ in the intestine, rendering the toxin unavailable for absorption (Southern et al., 1994). Ingestion of HSCAS to broilers does not improve skin pigmentation (Brake, 1987). The sorbent additives have raised questions about their effects on minerals and vitamins status, although Chung and Baker (1990) with P, Chung et al. (1990) with riboflavin and Southern et al. (1994) and Qota (2003) with $\mathrm{Ca}$ and $\mathrm{P}$, have reported that HSCAS does not impair the nutrient utilization. Glutathione $(\mathrm{GSH})$ is a tripeptide which found almost in its reduced form. It contains an unusual peptide linkage between the amino group of cystine and the carboxyl group of the glutamate. It is an antioxidant, protects cells from toxins such as free radicals during the tissue-damaging peroxidation process and increases enzymatic detoxification in the liver (Wattenberg, 1976). Epoxidation of the 2,3-double bond has been emphasized as a metabolic activation step and recent results indicate that the 2,3-epoxide is a reactive metabolite responsible for reaction with cellular macromolecules, as nucleic acids, and thus may well be the ultimate carcinogen (Swenson et al.,1977). Most damaging epoxidation form is $\mathrm{AFB}_{1}$ epoxide. The present study was designed to evaluate he effect of TF, HSCAS and/or GSH to reduce aflatoxicosis in laying hens.

\section{MATERIALS AND METHODS}

The present study was conducted at Sakha Animal Research Station and Laboratories, APRI, ARC, Egypt during Feb.-May 2007 to study the effects of sorbent materials as TF or HSCAS and antioxidants as GSH on laying performance during aflatoxicosis. A total number of 371 (350 hens +21 cocks) thirty-wks old ElSalam (Nicolas $\times$ Mamourah) chickens were divided into 7 similar $(B W=1450 \pm 23 \mathrm{~g}$ ) experimental groups ( 5 replicates of 10 hens each) and housed in metallic batteries. The remaining 25 cocks were also divided into 7 groups of 3 cocks each and housed separately for semen collection. Basal diet was formulated to cover nutrient requirements (Table 1) according to Egyptian Feed Composition Tables (2001). Birds were fed basal diet (control) without or with $1 \mathrm{ppm} \mathrm{AFB}_{1}$ alone (AF-diet) or plus either 5ppm tripeptide glutamate (reduced glutathione) (AF+GSH), $0.6 \%$ Tafla $(\mathrm{AF}+\mathrm{TF}), 0.5 \% \mathrm{HSCAS}(\mathrm{AF}+\mathrm{AS}), 0.6 \% \mathrm{TF}+5 \mathrm{ppm} \mathrm{GSH}(\mathrm{AF}+\mathrm{TF}+\mathrm{GSH})$ or $0.5 \%$ 
HSCAS+ 5ppm GSH (AF+AS+ GSH) to form 7 experimental diets fed from 30 to 38 wks old. Aflatoxin was produced via fermentation of rice by Aspergillus parasiticus NRRL 2999 as described by Shotwell et al. (1966) and modified by West et al. (1973). Fermented rice was autoclaved, dried and ground to a fine powder which was analyzed for its AF content by method of Nabney and Nesbitt (1965) as modified by Wiseman et al. (1967). The $\mathrm{AFB}_{1}$ in the rice powder was extracted by chloroform then incorporated into basal diet and confirmed by HPLC to provide the desired level of $1 \mathrm{ppm}$. The GSH (tripeptide glutamate) were purchased (L.E. $12 / \mathrm{g}$ ) from Sigma.

Table 1.Composition of the laying hen basal diet, HSCAS and tafla

\begin{tabular}{|c|c|c|c|c|}
\hline Ingredient & $\%$ & Composition $^{3}$ & HSCAS (\%) & Tafla (\%) \\
\hline Yellow corn & 64.84 & & & \\
\hline Soybean meal, $44 \%$ & 24.60 & Silica & 64.70 & 59.80 \\
\hline Dicalcium Phosphate & 1.70 & Aluminum & 15.50 & 17.20 \\
\hline Limestone & 7.60 & Iron & 1.75 & 2.30 \\
\hline $\mathrm{NaCl}$ & 0.30 & Calcium & 1.26 & 1.90 \\
\hline Vit. + Min. Mix. ${ }^{1}$ & 0.30 & Potassium & 1.80 & 2.30 \\
\hline Dl-Methionine & 0.06 & Sodium & 2.55 & 2.90 \\
\hline Clean sand & 0.60 & Magnesium & 1.54 & 1.90 \\
\hline Calculated values ${ }^{2}$ : & & Moisture & 10.56 & 10.32 \\
\hline $\mathrm{ME}, \mathrm{Kcal} / \mathrm{Kg}$ & 2723 & Price, LE/kg & 15.0 & 0.50 \\
\hline Lysine, & 0.88 & & & \\
\hline Meth. + Cys., $\quad \%$ & 0.62 & & & \\
\hline Av. Phosphorus, \% & 0.46 & & & \\
\hline Calcium, & 3.30 & & & \\
\hline \multicolumn{5}{|c|}{ Determined analyses ${ }^{3}$ : } \\
\hline Dry matter, $\quad \%$ & 89.51 & & & \\
\hline Crude protein, \% & 16.55 & & & \\
\hline Crude fiber, $\%$ & 3.22 & & & \\
\hline Ether extract, $\%$ & 2.66 & & & \\
\hline Crude ash, $\quad \%$ & 9.75 & & & \\
\hline Aflatoxin $\mathrm{B}_{1}$, ppb & 6.0 & & & \\
\hline Price, LE/Kg & 1.50 & & & \\
\hline
\end{tabular}

Aldrich Quimica S.A. Madrid 28100, Spain). The HSCAS was purchased from Integrated World Enterprises Co.. Tafla (available natural substance) was washed, grounded to a fine powder. Chemical analyses for HSCAS and tafla (Table 1) were done (AOAC, 1990). Feed intake, egg number and egg weight were recorded weekly. Shell thickness using Micrometer were estimated 3 times (18 d intervals) using 50 eggs/group/time and the yolk was separated for analysis. Hens were artificially inseminated once a week. During the last 2 wks of the experimental period, eggs laid were collected, stored for $5 \mathrm{~d}$ at $18^{\circ} \mathrm{C}$ then incubated to estimate fertility and hatchability. At the end of the experiment, five hens/group were slaughtered for 
tissues analyses. Liver lipid was extracted (Folch et al.,1957). Liver vit. A (as retinol) content was estimated (Thompson et al., 1971). Also, $\mathrm{AFB}_{1}$ residues in fresh meat (breast:thigh, 1:1), liver and egg yolk were measured (Stubblefield et al., 1982). Blood hemoglobin (Hb) (Kampen and Zijlestra, 1961), total leucocytes (WBC's) and lymphocyte counts (Wintrobe, 1969), serum albumin (Doumas et al, 1977), total lipids (ChabrIol and Charonnat, 1973) and alanine aminotransferase (ALT) and aspertate aminotransrerase (AST) enzymatic activities (Reitman and Frankel,1957) were measured using commercial kits. Data were statistically analyzed using oneway ANOVA of GLM procedure of Statistical Analysis Software (SAS,1994). Significant differences among treatment means were separated by Duncan's new multiple range test (Duncan, 1955) with 5\% level of probability.

\section{RESULTS AND DISCUSSIONS}

\section{Productive and reproductive performance and economic efficiency :}

There was similar trend for treatments effect on the studied traits. Data presented in Table 2 show that contamination of basal diet with 1 ppm $\mathrm{AFB}_{1}$ for 8 wks significantly $(\mathrm{P}<.01)$ impaired feed intake $(25.1 \%)$, egg production $(42.8 \%)$, egg weight $(22.3 \%)$, shell thickness $(32.6 \%)$ eggs fertility $(21.9 \%)$, hatchability of fertile eggs $(20 \%)$ and economic efficiency (EE) (38.47\%) compared to the controls. Inclusion of $0.6 \%$ TF or $0.5 \%$ HSCAS separately with AF-diet recorded similar protection effects $(\mathrm{P}<.01)$ averaged $47-56 \%$ for productive and reproductive traits against aflatoxicosis. Adding $5 \mathrm{ppm}$ GSH alone with AF-diet had little protective effects on laying performance traits studied. While GSH with TF or with HSCAS supplemented to AF-diet significantly prevented aflatoxicosis as assessed by performance traits (Table 2). Supplementing sorbent materials plus GSH with AFdiet improved EE $80.97 \%$ for $\mathrm{TF}+\mathrm{GSH}$ and $74.87 \%$ for $\mathrm{HSCAS}+\mathrm{GSH}$ compared to AF-diet. There were mortalities only among two groups fed basal diet with $\mathrm{AFB}_{1}$ alone $(10 \%)$ and $\mathrm{AFB}_{1}+\mathrm{GSH}(6 \%)$. Many authors used 1-3 ppm AF (Edrington et al.,1997; Genedy et al.,1999; Ali et al.,2006) with different chicken strains and showed similar deterioration in laying performance traits by AF-diet. Lack of essential nutrients such as minerals and vitamins, as a result of feed intake decrease, and inhibition of metabolism and immunity system by aflatoxicosis may explain the present impairments of egg production, shell thickness and reproductive traits as those showed by Smith and Hamilton (1970). Regarding sorbent materials protection, the present results confirmed those of Genedy et al. (1999) and Ali et al. (2006). They showed, working on different chicken strains, that adding $0.5 \%$ HSCAS to basal diet contaminated with AF did diminished aflatoxicosis impact on productive and reproductive traits by about 50-60\%. Tafla and HSCAS had similar protective effect against aflatoxicosis as they contain similar chemical compounds (Table 1).

They sorbed $\mathrm{AFB}_{1}$ selectively during the digestive process, which rendered most of the AF unavailable for absorption from the gastrointestinal tract as those reported by Huff et al. (1992), Kubena et al. (1993) and Qota (2003). 
Table 3. Liver status and hematological traits of El-Salam laying hens fed dietary treatments from 30 to 38 wks old

\begin{tabular}{ccccccc}
$\begin{array}{c}\text { Dietary } \\
\text { treatment }\end{array}$ & $\begin{array}{c}\text { Liver } \\
\text { wt. } \\
(\%)\end{array}$ & $\begin{array}{c}\text { Liver } \\
\text { lipids } \\
(\%)\end{array}$ & $\begin{array}{c}\text { Liver } \\
\text { vit. A } \\
(\mu \mathrm{g} / \mathrm{g})\end{array}$ & $\begin{array}{c}\text { Leuco- } \\
\text { cytes } \\
\left(10^{3} / \mathrm{mm}^{3}\right)\end{array}$ & $\begin{array}{c}\text { Lymph- } \\
\text { ocytes } \\
\left(10^{3} / \mathrm{mm}^{3}\right)\end{array}$ & $\begin{array}{c}\text { Hemo- } \\
\text { globin } \\
\mathrm{mg} / 100 \\
\mathrm{ml}\end{array}$ \\
\hline Control & $3.12^{\mathrm{c}}$ & $5.35^{\mathrm{c}}$ & $21.47^{\mathrm{a}}$ & $21.4^{\mathrm{c}}$ & $14.83^{\mathrm{c}}$ & $12.61^{\mathrm{a}}$ \\
AF-diet & $7.45^{\mathrm{a}}$ & $12.94^{\mathrm{a}}$ & $15.22^{\mathrm{c}}$ & $27.4^{\mathrm{a}}$ & $18.87^{\mathrm{a}}$ & $8.19^{\mathrm{c}}$ \\
$\mathrm{AF}+\mathrm{GSH}$ & $6.33^{\mathrm{ab}}$ & $11.02^{\mathrm{ab}}$ & $16.79^{\mathrm{bc}}$ & $25.9^{\mathrm{ab}}$ & $17.80^{\mathrm{ab}}$ & $9.21^{\mathrm{bc}}$ \\
$\mathrm{AF}+\mathrm{AS}$ & $5.31^{\mathrm{b}}$ & $9.18^{\mathrm{b}}$ & $18.36^{\mathrm{b}}$ & $24.5^{\mathrm{b}}$ & $16.78^{\mathrm{b}}$ & $10.31^{\mathrm{b}}$ \\
$\mathrm{AF}+\mathrm{TF}$ & $5.34^{\mathrm{b}}$ & $9.22^{\mathrm{b}}$ & $18.34^{\mathrm{b}}$ & $24.6^{\mathrm{b}}$ & $16.82^{\mathrm{b}}$ & $10.33^{\mathrm{b}}$ \\
$\mathrm{AF}+\mathrm{AS}+\mathrm{GSH}$ & $4.22^{\mathrm{bc}}$ & $7.33^{\mathrm{bc}}$ & $19.90^{\mathrm{bc}}$ & $23.0^{\mathrm{bc}}$ & $15.77^{\mathrm{bc}}$ & $11.51^{\mathrm{ab}}$ \\
$\mathrm{AF}+\mathrm{TF}+\mathrm{GSH}$ & $4.21^{\mathrm{bc}}$ & $7.36^{\mathrm{bc}}$ & $19.94^{\mathrm{bc}}$ & $22.9^{\mathrm{bc}}$ & $15.81^{\mathrm{bc}}$ & $11.53^{\mathrm{ab}}$ \\
SEM & 0.194 & 0.251 & 0.873 & 3.214 & 2.14 & 0.308 \\
P value & 0.001 & 0.003 & 0.006 & 0.006 & 0.005 & 0.011 \\
\hline
\end{tabular}

${ }^{\mathrm{a}-\mathrm{d}}$ Values followed by different letters within columns are significantly different $(\mathrm{P}<0.05)$.

${ }^{1} \mathrm{AF}=1 \mathrm{ppm}$ Aflatoxin $\mathrm{B} 1, \mathrm{TF}=0.6 \%$ Tafla, $\mathrm{AS}=0.5 \%$ Hydrated sodium calcium aluminosilicate (HSCAS), GSH=5 ppm Glutathione (Tripeptide glutamate). Values are means of five determinations.

\section{Aflatoxin $B_{1}$ residues in fresh tissues and serum constituents:}

Results of Table 4 show that birds fed basal diet contaminated with $1 \mathrm{ppm}$ AFB1 for 8 wks deposited $\mathrm{AFB}_{1}$ residues by highest value in their fresh livers (68 $\mathrm{ng} / \mathrm{g}$ ) followed by egg yolk (52 ng/g) then muscles (36 ng/g), decreased serum albumin $(68 \%)$ and total lipids $(51 \%)$ and increased enzymatic activities of AST $(64 \%)$ and ALT $(69 \%)$. Adding TF or HSCAS to AF diet, similarly, reduced AFB1 residues by 51,48 , and $50 \%$ in the yolk, liver and meat; respectively, and diminished AF effects on albumin, lipids, AST and ALT by 56, 46, 49 and 51\%; respectively. A significant alleviating effect for adding GSH separately to the AF diet was observed with AST and ALT. Moreover, adding GSH with TF or HSCAS to the AF diet significantly negated the adverse effect of the AF diet on serum constituents, and reduced the $\mathrm{AFB}_{1}$ residues by 75,74 and $75 \%$ in yolk, liver and meat; respectively. The present results confirmed those of Qota (2003), Ali et al. (2006) and Hassan (2006) who detected $\mathrm{AFB}_{1}$ residues in tissues of birds fed contaminated diets. Increasing accumulation $\mathrm{AFB}_{1}$ in the liver than other tissues, in the present study, was observed also by Rizk et al. (1993), Abdelhamid et al. (1995b) and Qota et al. (2005). Decreasing serum albumin and lipids, and increasing ALT and AST activities by aflatoxicosis were reported in many studies (Genedy et al., 19999; Hassan, 2000; Qota et al., 2005). The protective effect of sorbent materials against AF diet for AFB1 residues and serum constituents, in the present study, was observed also by Kubena et al. (1993), Genedy et al. (1999) and Qota et al. (2005).

Few studies have been carried on glutathione as detoxification of AF. Role of GSH comes after the absorption of AF and during its metabolism process in the liver. It, as an antioxidant, protects cells from toxins such as free radicals during the tissue-damaging peroxidation process and increases enzymatic detoxification in the liver (Wattenberg, 1976). Ehrich et al. (1984) and Ehrich and Larsen (1983) proved 
that detoxification enzyme systems in chickens could be increased by the administration of the antioxidants. Hsieh (1982) found that primary hepatic metabolites of $\mathrm{AFB}_{1}$ may subjected to cytoplasmic reductase system producing aflatoxicol or to liver microsomal oxidase system producing $A F: Q_{1}, M_{1}$ and $B_{1}$ epoxide. Except for $\mathrm{AFB}_{1-}$ epoxide, all metabolites contain hydroxyl groups are transformed into a water-soluble conjugate and to facilitate excretion. The transient $\mathrm{B}_{1}$-epoxide can be conjugated by $\mathrm{GSH}$ to form another type of conjugate. A prospective action may be afforded by reaction of $\mathrm{AFB}_{1}$ metabolite with GSH (Lotikar et al., 1980). Presence of $\mathrm{AFB}_{1}-\mathrm{GSH}$ conjugate in the bile of AF-treated rats, and its formation in vitro in liver-derived subcellular fractions, has been reported (Dengen and Neumann, 1978; Moss et al, 1983). Some nutrients increased the activity of GSH for detoxification of AF in birds tissue such as Se is used as a cofactor for Se dependent GSH peroxidase (SeGSHpx) which is important in detoxification of hydrogen-px and lipid hydro-px, and increase GSH-px activity (Combs, 1981). Only Se increased the activity of Se GSH-Px in all tissues (Combs, 1981; Nahm, 1995). Also, Se enhanced the formation of water-soluble conjugated forms of AF which promotes the clearance of the toxin (Gregory and Edds 1984). In the same manner methionine is a more distal precursor of GSH (Veltmann et al., 1983). Vitamin C affected GSH metabolism at low concentration (Kim and Combs, 1992). From the results of the present study, it may be concluded that TF had a similar protective effect as HSCAS and adding GSH as antioxidant with TF or HSCAS, as sorbent materials to AF diet significantly negated aflatoxicosis in the laying hens.

Table 4. Aflatoxin $B_{1}$ residues in fresh tissues and serum constituents of Elsalam laying hens fed dietary treatments during 30-38 wks old

\begin{tabular}{clcccccc}
\hline \multirow{2}{*}{$\begin{array}{c}\text { Dietary } \\
\text { treatment }\end{array}$} & \multicolumn{3}{c}{ AFB $_{1}$ residues } & \multicolumn{5}{c}{ Serum constituents } \\
\cline { 2 - 8 } & $\begin{array}{l}\text { Yolk } \\
(\mathrm{ng} / \mathrm{g})\end{array}$ & $\begin{array}{c}\text { Liver } \\
(\mathrm{ng} / \mathrm{g})\end{array}$ & $\begin{array}{c}\text { Meat } \\
(\mathrm{ng} / \mathrm{g})\end{array}$ & $\begin{array}{c}\text { Albumin. } \\
\mathrm{g} / 100 \mathrm{ml}\end{array}$ & $\begin{array}{c}\text { Lipid } \\
(\mathrm{g} / \mathrm{l})\end{array}$ & $\begin{array}{c}\text { AST } \\
(\mathrm{IU} / \mathrm{L})\end{array}$ & $\begin{array}{c}\text { ALT } \\
(\mathrm{IU} / \mathrm{L})\end{array}$ \\
\hline Control & $* * *$ & $* * *$ & $* * *$ & $2.5^{\mathrm{a}}$ & $6.7^{\mathrm{a}}$ & $12.1^{\mathrm{e}}$ & $7.52^{\mathrm{e}}$ \\
$\mathrm{AF}-$ diet & $51.6^{\mathrm{a}}$ & $67.8^{\mathrm{a}}$ & $36.4^{\mathrm{a}}$ & $0.8^{\mathrm{c}}$ & $3.3^{\mathrm{c}}$ & $19.8^{\mathrm{a}}$ & $12.7^{\mathrm{a}}$ \\
$\mathrm{AF}+\mathrm{GSH}$ & $37.2^{\mathrm{ab}}$ & $51.5^{\mathrm{ab}}$ & $27.3^{\mathrm{ab}}$ & $1.2^{\mathrm{bc}}$ & $4.2^{\mathrm{bc}}$ & $17.6^{\mathrm{b}}$ & $11.4^{\mathrm{b}}$ \\
$\mathrm{AF}+\mathrm{AS}$ & $25.5^{\mathrm{b}}$ & $34.3^{\mathrm{b}}$ & $18.2^{\mathrm{b}}$ & $1.6^{\mathrm{b}}$ & $5.1^{\mathrm{b}}$ & $15.8^{\mathrm{c}}$ & $10.1^{\mathrm{c}}$ \\
$\mathrm{AF}+\mathrm{TF}$ & $24.9^{\mathrm{b}}$ & $33.9^{\mathrm{b}}$ & $18.4^{\mathrm{b}}$ & $1.5^{\mathrm{b}}$ & $5.2^{\mathrm{b}}$ & $15.9^{\mathrm{c}}$ & $10.2^{\mathrm{c}}$ \\
$\mathrm{AF}+\mathrm{AS}+\mathrm{GSH}$ & $13.4^{\mathrm{bc}}$ & $17.6^{\mathrm{bc}}$ & $9.21^{\mathrm{bc}}$ & $2.2^{\mathrm{ab}}$ & $6.2^{\mathrm{ab}}$ & $14.0^{\mathrm{d}}$ & $8.79^{\mathrm{d}}$ \\
$\mathrm{AF}+\mathrm{TF}+\mathrm{GSH}$ & $12.8^{\mathrm{bc}}$ & $18.2^{\mathrm{bc}}$ & $9.09^{\mathrm{bc}}$ & $2.1^{\mathrm{ab}}$ & $6.0^{\mathrm{ab}}$ & $13.9^{\mathrm{d}}$ & $8.81^{\mathrm{d}}$ \\
SEM & 1.98 & 2.17 & 1.88 & 0.31 & 0.51 & 1.01 & 0.71 \\
P value & 0.003 & 0.001 & 0.004 & 0.002 & 0.01 & 0.01 & 0.01 \\
\hline
\end{tabular}

$\overline{\mathrm{a}-\mathrm{d}}$ Values followed by different letters within columns are significantly different $(\mathrm{P}<0.05)$.

${ }^{1} \mathrm{AF}=1 \mathrm{ppm}$ Aflatoxin $\mathrm{B} 1, \mathrm{TF}=0.6 \%$ Tafla, $\mathrm{AS}=0.5 \%$ Hydrated sodium calcium aluminosilicate (HSCAS), GSH=5 ppm Glutathione (Tripeptide glutamate). Values are means of five determinations.

$* * *=$ No detection of $\mathrm{AFB} 1^{-}$ 


\section{ACKNOWLEDGEMENT}

Appreciation is expressed to staff members of the Mycotoxin Lab., NRC; Soil and Water Dept. at Sakha Station, ARC and Feed Analysis Unit, APRI, ARC for supports and technical assistance.

\section{REFERENCES}

Abdelhamid, A.M., T.M. Dorra and H.S.M. Arief, 1995a. Effect of some dietary supplements to aflatoxic diets of chickens. 1. On the performance. J. Agric. Sci. Mansoura Univ., 20: 3208.

Abdelhamid. A.M., H.S. Arief; F. El-Keraby and T.M. Dorra, 1995b. Effect of some dietary supplements to aflatoxic diets of chickens. 2. On the tissue analysis. J. Agric. Sci. Mansoura Univ., 20: 3227.

Abd El-Hamid, H.S., A.G.R. Shakshouk, M. Korshom, E.M. El-Manakhly and A.B.A. Bekhiet, 1992. Effect of aflatoxin on broiler chickens. Egypt. Poult. Sci., 12: 443 .

Ali, M.N., E.M.A. Qota, R.A. Hassan and Abou-El maged, 2006. Novel methods of detoxification of aflatoxin B1 in contaminated local laying hen diets. Egypt. Poult. Sci.. 26: 911-940.

AOAC, 1990. Association of Official Analytical Chemistry. Official methods of analysis $15^{\text {th }}$ ED Published by AOAC Washington, DC.

Brake, J., 1987. Field results on broiler chickens with a selected aluminosilicate. Pages F1-F11 in: Proc. Symp. On the recent developments in study of Mycotoxins, December.17, 1987, Rosemont.

Chabrol, E. and R. Charonnat, 1973. Method for determination of serum total lipids. Press. Medical, 45:1713-1716.

Chung, T.K. and D.H. Baker, 1990. Phosphorus utilization in chicks fed hydrated sodium calcium aluminosilicate. Anim. Sci., 68:1992-1998.

Chung, T.K., J.W. Erdman and D.H. Baker, 1990. Hydrated sodium calcium aluminosilicate: Effects on zinc, manganese, vitamin A and riboflavin utilization. Poult. Sci., 69: 1364-1370.

Combs, G.E., 1981. Influence of dietary vitamin $\mathrm{E}$ and selenium on the oxidant defense system of the chicks. Poult. Sci., 60: 2098-2105.

Dengen, G.H. and H.G. Neumann, 1978. The major metabolite of aflatoxin B1 in the rat is a glutathione conjugate. Chemicobiological Interactions, 22:239-243.

Doumas, B.T.; W.A. Watson and H.G. Biggs, 1977. Albumin standards and the measurements of serum albumin with bromocrisol green. Clin. Chem. Acta. 31: 87.

Duncan, D.B., 1955. Multiple range and multiple F-test. Biomet., 11:1-42.

Edrington, T.S., L.F. Kubena, R.B. Harvey and G.E. Rotinghaus, 1997. Influence of a superactivated charcoal on the toxic effects of aflatoxin or T-2 in growing broilers. Poult. Sci., 76: 1205.

Egyptian Feed Composition Tables for Animal and Poultry Feedstuffs, 2001. Technical bulletin No. 1, central lab. for feed and food, Ministry of Agric., Egypt. 
Ehrich, M. and C. Larsen, 1983. Drug metabolism in adult White Leghorn hensresponse to enzyme inducers. Comprehensive Biochemistry and Physiology, 74c: 383-386.

Ehrich, M.; W.R. Huckle and C. Larsen, 1984. Increase in glucuronide conjugation of aflatoxin P1: after pretreatment with microsomal enzyme inducers. Toxicology, 32: $145-152$.

El-Samra, S.H., 1991. Aflatoxin and poultry nutrition. Proc. $3^{\text {rd }}$ Sci. Symp. For Anim., Poult. and Fish Nutr.. Sakha, Egypt, 26-28 November, P:30.

Folch, J., Lees, M.E. and Stanley, G.H.S., 1957. A simple method for the isolation and purification of total lipids from animal tissues. J. Biol.Chem., 226:407-409.

Genedy, S.G.K.; N.M. El-Naggar; N.S. Isshak and E.M.A. Qota, 1999. Effect of aflatoxins contaminating agents on performance, blood constituents and some tissues of local poultry strains. Egypt. Poult. Sci., 19; 351-377.

Gregory, J.F. and G.T. Edds, 1984. Effects of dietary selenium on the metabolism of aflatoxin of young turkeys and broiler chicken. Poult. Sci. 64: 1678-1684.

Hassan, R.A., 2000. Studies on the effect of certain feed-additives on the performance of broilers and layers fed aflatoxicated feed. Ph.D Thesis Fac. of Agric. Tanta Univ.

Hassan, R.A., 2006. Capability of mannan-oligosaccharide (Bio-mos ${ }^{\circledR}$ ), organic selenium and hydrated sodium calcium aluminosilicate to detoxify aflatoxicosis for growing local chickens. 2. Lymphoid organs, immune response and residues in tissues. Egypt. Poult. Sci. 26: 495-511.

Hsieh, P.H. Dennis, 1982. Metablism and transmission of mycotoxins. Proc. Int. Sym. Mycotoxins, P:151.

Huff, W.E., T.F. Kubena, R.B. Harvey and T.D. Phillips, 1992. Efficacy of hydrated sodium calcium aluminosilicate to reduce the individual and combined toxicity of aflatoxin and ochratoxin A. Poult. Sci., 71: 64.

Kampen, E.J. and W.G. Zijlestra, 1961. Standarization of Hemoglobino-metry. 11-The hemoglobin cyanidemethod. Clin. Chem. Acta. 61:538.

Kim, Y.S. and G.E. Combs, 1992. Effects of selenium and vitamin E and C on glutathione and glutathione S-transferase in the chicks. Cornell Nutrition Conference, PP: 37-42.

Kubena, T.F., R.B. Harvey and T.D. Phillips and B.A. Clement, 1993. Effect of hydrated sodium calcium aluminosilicate on aflatoxicosis in broiler chicks. Poult. Sci., 72: 651 .

Kubena, T.F., W.E. Huff, R.B. Harvey, A.G. Yersin, M.H. Elissable, D.A. Witzel, L.E. Giroir; T.D. Phillips and H.D. Peterson, 1995. Effect of a Hydrated sodium calcium aluminosilicate on growing turkey poults during aflatoxicosis. Poult. Sci., 70: 1823 .

Lotiker, P.D.; S.M. Setta; P.A. lyons and E.C. Jhee, 1980. Inhibition of microsomemediated binding of aflatoxin B1 to DNA by glutathione S-transferase. Cancer letters, 9:143-149.

Moss, E.J.; D.J. Judah; M. Przybylski and G.E. Neal, 1983. Some mass-spectral and n.m.r. analytical studies of a glutathione conjugate of aflatoxin B1. Biochemical J., 210: 227-234.

Nabney, J. and B.F. Nesbitt, 1965. A spectrophotometric method of determining the aflatoxin. Anaslyst, 90: 155-160. 
Nahm, K.H., 1995. Prevention of aflatoxicosis by addition of antioxidants and hydrated sodium calcium aluminosilicate to the diet of young chicks. Japanese Poult. Sci. 32: 117-127.

Phillips, T.D., L.F. Kubena, R.B. Varvey, D.R. Taylar and N.D. Heidelbaugh, 1988. Hydrated sodium calcium aluminosilicate a high affinity sorbent for aflatoxin. Poult. Sci., 67: 243-247.

Reitman, S. and S. Frankel, 1957. Method for determination of amino transferase enzymatic activities. Amer. J. Clin. Path., 28: 56.

Rizk, R.E., N.A. El-Sayed, G.A. Abd-Allah and S.A. El-Deeb, 1993. The residue of low dietary aflatoxin B1 and its effect on productivity and reproductively of local chicken strains. Egypt. Poult. Sci., 13: 301.

Qota, E.M.A., 1999. Effectiveness of some feed additives for detoxification of mycotoxin contaminated local chicken diets. Ph.D. Thesis Fac. of Agric. Tanta Univ.

Qota, E.M.A., 2003. Hydrated sodium calcium aluminosilicate effects on some mineral and vitamin status during aflatoxicosis in growing turkey. J. Agric. Sci. Mansoura Univ., 28(3): 1729-1743.

Qota, E.M.A., M.A. Ali, R.A. Hassan and M.K. Abou-El Maged, 2005. Detoxification of aflatoxin contaminated local chicken diets using Aluminosilicate, sodium sulphate and peroxidase enzyme. $3^{\text {rd }}$ International poultry conference 4-7 Apr. 2005 Hurgada, Egypt.

SAS Institute, 1994. SAS/STAT user's guide: statistics, version 6 Edition. SAS Institute Inc. Cary., Nc, USA.

Scheideler, S.E., 1993. Effect of various types of Aluminosilicate and aflatoxin B1on aflatoxin toxicity, chicken performance and mineral status. Poult. Sci.,72: 282.

Shotwell, O.L., C.W. Hesseltine, R.D. Stubbefield and W.G. Sorenson, 1966. Production of aflatoxin on rice. Appl. Microbiol., 14: 425.

Smith, J.W. and P.B. Hamilton (1970). Aflatoxicosis in broiler chicken. Poult. Sci., 49: 207.

Smith, M.O., D.S. Sachan and Y.S. Cha, 1993. Effect of L-carnitine on aflatoxin toxicity in broilers. Poult. Sci. Abst., (136): 129.

Southern, L.L.; T.L. Ward; T.D. Bidner and L.G. Hebert, 1994. Effect of sodium bentonite or hydrated sodium calcium aluminosilicate on growth performance and tibia mineral concentration in broiler chicks fed nutrient-deficient diets. Poult. Sci., 73: 848-854.

Stubblefield, R.D.; W.F. Kwolek and L. Stoloff, 1982. Determination and thin layer chromatographic confirmation of identify of aflatoxin B1 and M1 in artificially contaminated beef livers. Collaborative Study. J. Assoc. of Anal. Chem., 65 (6): 1435.

Swenson, D.H.; J.K. Lin; E.C. Miller; J.A. Miller, 1977. Aflatoxin B1-2,3-oxide as a probable intermediate in the covalent bending of aflatoxin B1 and B2 to rat liver DNA and ribosomal RNA in vivo. Cancer Research, 37:172-181.

Thompson, J.N., P.A. Erdody, R. Brien and T.K. Mussay, 1971. Flurometric determination of vitamin A in human blood and liver. Biochem. Med.,5:67-89.

Veltmann, J.R., R.D. Wyatt, M.N. Voight and Z. Shamsuddin, 1983. Influence of dietary sulfur amino acid levels on performance, free amino acids and 
biochemical parameters in plasma and hepatic glutathione of broiler chicks fed aflatoxin. Poult. Sci. 62: 1518-1519.

Wattenberg, L., 1976. Inhibition of chemical carcinogenesis by antioxidants and some additional compounds. In: Fundamentals in Cancer Prevention, Univ. of Tokyo Press, Tokyo, Japan: 153-166.

West, S., R.D. Wyatt and P.B. Hamilton, 1973. Improved yield of aflatoxin by incremental increases in temperature. Appl. Microbiol. 25: 1018.

Wild, C.P., Y.Z. Jiang, G. Sabbioni, B. Chapot and R. Montesano, 1990. Evaluation of methods for quantitation of aflatoxin albumin adducts and their application to human exposure assessment. Cancer. Res., 50: 245.

Wintrobe, M.M., 1969. Clinical Haematol., $6^{\text {th }}$ Ed., Henery Kimpton Lond.

Wiseman, H.G., W.C. Jacobsn and W.E. Harmeyer, 1967. Note of removal of pigments from chloroform extracts of aflatoxin cultures with copper carbonate. J. Assoc. Agric. Chem., 50: 982.

Zilva, J.F. and P.R. Pannall, 1983. Clinical chemistry in diagnosis and treatment. $3^{\text {rd }}$ Ed. Loyd-Luke. (Medical Books) LTD, London. 
تأثير الجلوتاثيون والالومنيوم سيليكات والطقله في العلف على الدجاج البياض أثناء التسمم بالافلاتوكسينات

\section{الثحات محمد عبد الحليم قوطة ، النبوي حامد الجنزورى ، رضا على حسن \\ قسم بحوث تغذية الدواجن - معطج بحوث الإنتاج الحيوانس- مركز البحوث النزاعية- جيزة- مصر}

أجريت تجربه لنقييم كفاءة كل من الجلوتاثيون (تراى بيتيد جلوتامات) كمضاد أكسده والطفلة والالومنيوم

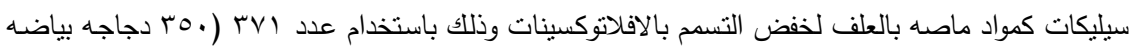

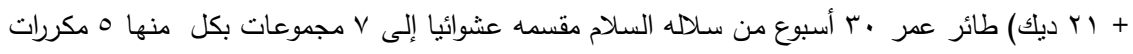

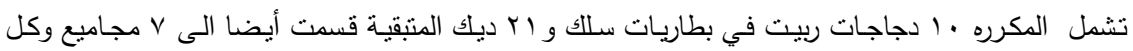

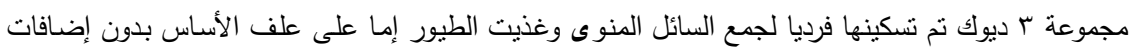

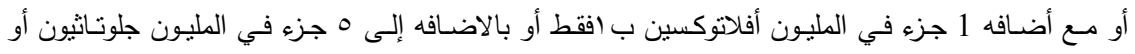

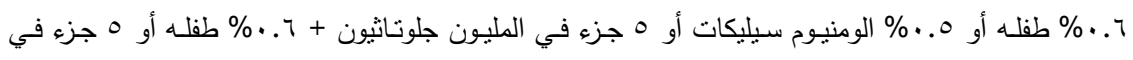

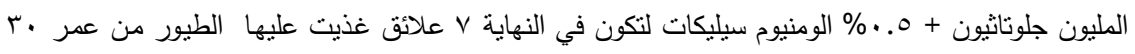

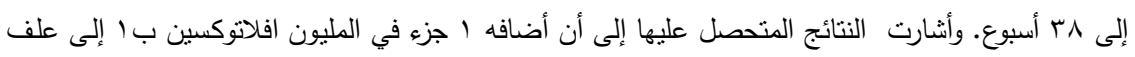

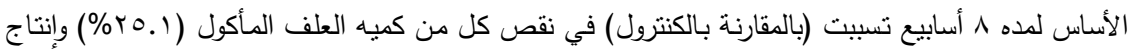

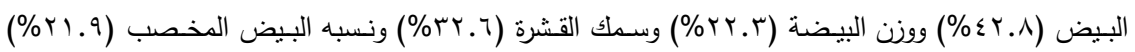

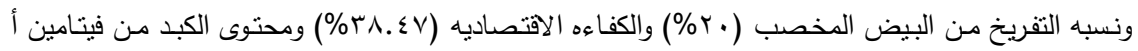

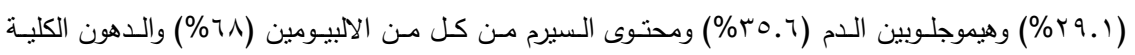

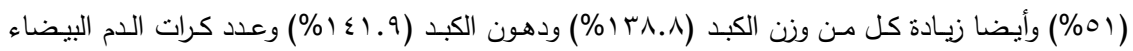

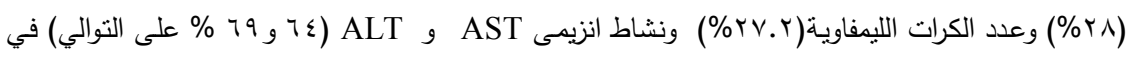

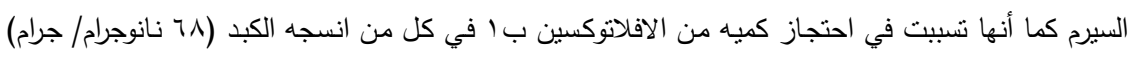

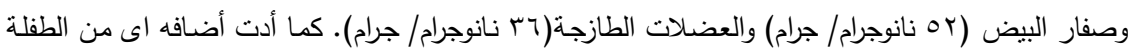

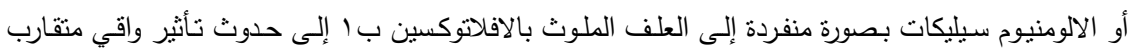

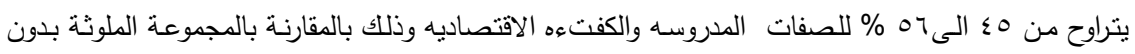

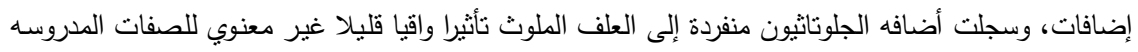

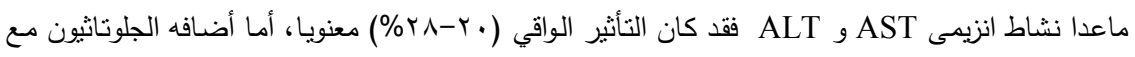

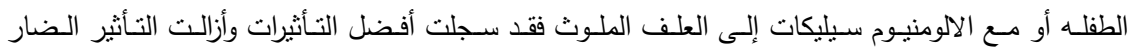

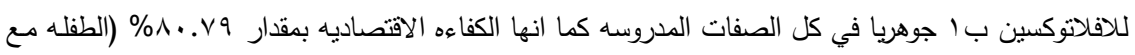

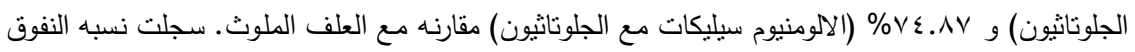

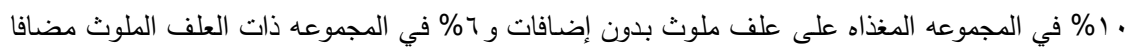

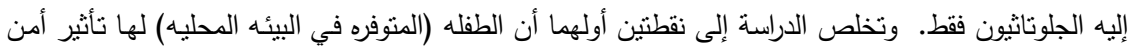


وواقي ضـ الافلاتوكسين ب ا مساويا تمامـا فى جميع القياسات والكفاءه الاقتصاديه مـع الالومنيوم سيليكات

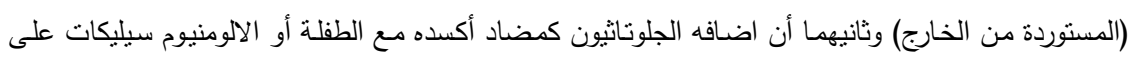

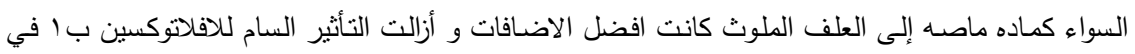
الدجاج اليياض ويحتاج هذا الموضوع إلى مزيد من الدراسات تأكيديه. 